\title{
Export Dependence and Sustainability of Growth in China
}

\author{
Yılmaz Akyüz *
}

\begin{abstract}
A bstract
This paper examines the contribution of exports to growth in China since the early years of the decade. It is estimated that, despite a high import content ranging between 40 and 50 percent, approximately one-third of Chinese growth before the global crisis was a result of exports, due to their phenomenal growth of some 25 percent per annum. This figure increases to 50 percent if spillovers to consumption and investment are allowed for. The main reason for excessive dependence on foreign markets is underconsumption. This is due not so much to a high share of household savings in GDP as to a low share of household income and a high share of profits. It is argued that China can no longer maintain such high growth rates for its exports, and, therefore, needs to turn to consumption-led growth by expanding the share of wages and household income in GDP and accelerating public spending in social infrastructure.
\end{abstract}

K ey words: China, consumption-led growth, export dependence, income distribution, trade and growth

J EL codes: F14,F43, D33, E1

\section{Introduction}

A key issue raised by the global economic crisis is the degree of dependence of growth in East Asian ${ }^{1}$ developing and emerging economies (DEE) on exports, particularly to the USA and the EU. Attention in this respect is often focused on China as the center of the East Asian production network and number one exporter, both in the region and globally. Already at the onset of the crisis, views differed widely as to whether growth in China would be

\footnotetext{
* Y1lmaz Akyüz, Special Economic Advisor, South Center, and former Director, Division on Globalization and Development Strategies, UNCTAD, Geneva, Switzerland. Email: yilmaz.akyuz@ bluewin.ch. The author is grateful to Michael Lim Mah-Hui, Martin Khor and Mehdi Shafaeddin and Yongding Yu for comments and suggestions, and to Xuan Zhang for assistance with the data used in this paper.

${ }^{1}$ For the purpose of this study, East Asia is defined to include the newly industrialized economies (NIEs; Korea, Taiwan, Singapore and Hong Kong), China and members of ASEAN, but to exclude Japan.
} 
decoupled from contraction of economic activity in advanced economies. Those who did not see exports playing a key role in China expected not only that growth in China would continue to surge ahead despite emerging difficulties in advanced economies, but that it could also prevent the world economy from falling into recession. For instance, it was argued that "as far as macro growth is concerned the [Chinese] economy is and has always been effectively 'decoupled', and China has little to fear from a global demand slowdown" because the "idea that China is an export-led economy" is a myth (Anderson 2007a, p. 1). A similar view was echoed in The Economist (2007), where it was argued that China's net exports accounted for approximately one-quarter of its growth in 2007 and that a US downturn was more likely to cause sniffles in China than a heavy cold. Even as the crisis deepened there were talks of reverse coupling, with the rest of the world, notably China, pulling the US forward and preventing it from falling into recession (Bergsten, 2008).

The principal channel of transmission of the adverse impact of the crisis to Asian DEE has been trade. As contraction started to take root in advanced economies, exports in Asia began to fall rapidly from the third quarter of 2008, with year-on-year declines reaching double digit figures across the region, after growing at similar rates in previous years. China escaped a collapse in growth thanks to a massive fiscal package and to aggressive easing of monetary policy. However, the sharp drop in exports has raised questions regarding whether China can return to rapid and sustained export-led growth as the world economy recovers from the crisis. Even before the outbreak of the global crisis there were doubts about the sustainability of China's growing penetration in the markets of advanced and developing economies. These concerns have increased considerably because of widespread expectations that global economic conditions in the coming years are likely to be significantly less favorable than in the boom years of 2002-2007. It is generally agreed that a return to "business as usual" would be a recipe for increased instability and deeper global crises, posing a threat to international monetary, trade and payments systems. Avoiding such an outcome would call for, inter alia, reductions in global trade imbalances. The US would need to live within its means and shift from consumption-led to export-led growth while China would need to restrain its export push and rely increasingly on domestic consumption. ${ }^{2}$ The realization that a return to "business as usual" might not be possible in fact underscores the search for a new growth model in East Asia, based on the expansion of domestic and regional markets.

The present paper addresses these issues. It starts with a simple analytical framework for the measurement of the contribution of exports and domestic demand to growth,

\footnotetext{
${ }^{2}$ However, as argued in Akyüz (2010), a US-China rebalancing alone would not be sufficient to secure global stability and growth.

(C)2011 The Author

China \& World Economy (C2011 Institute of World Economics and Politics, Chinese Academy of Social Sciences
} 
accounting for their import contents. The empirical evidence reviewed in this paper suggests that in recent years the average import content of Chinese exports has been between 40 and 50 percent and in value-added terms the share of exports in GDP is in the order of 20 percent. Despite the high import content of exports, however, one-third of growth of income in China in the years before the outbreak of the global crisis is estimated here to have been due to exports, which grew phenomenally, by some 25 percent per annum. This figure goes up to 50 percent if spillovers to domestic consumption and investment are accounted for. These figures are significantly higher than the estimates of some 15 percent produced by conventional accounting based on net exports.

This high degree of dependence on growth of exports is the outcome of underconsumption. In China, the share of private consumption in GDP has been falling since the late 1990s, from over 50 percent to approximately 36 percent. By contrast, investment has been rising faster than GDP and its share has now reached close to 50 percent by the policy response to contraction of exports. When investment grows faster than consumption, rapid expansion is required in foreign markets so that production capacity can be fully utilized, to create and maintain strong growth. However, if such an expansion is no longer feasible, consumption must grow faster than income and investment.

One reason for underconsumption is high precautionary savings by households because of inadequate public provision of basic needs, such as health care, education and housing. However, a more important reason is the low share of household income and a relatively high share of corporate profits in GDP. Much of household income consists of wages because government transfers and investment income are very small. The shares of wages and household income in GDP have been falling since the late 1990s and these are mirrored by the declining share of private consumption. By contrast, corporate profits and retentions as a proportion of GDP have been rising, contributing to national savings as much as and even more than household savings. Therefore, the disparity between consumption and investment and the consequent dependence on foreign markets is largely a reflection of the imbalance between wages and profits, and between household and corporate incomes. This needs to be rectified if rapid and sustained growth is to be attained based on the domestic market.

\section{Measurement of Contribution of Exports to Economic Growth}

The conventional approach to the measurement of contribution of exports to economic growth relies on demand-side growth-accounting based on ex-post national income identity. 
This involves decomposing income growth into its constituent parts, using observed growth rates of each component of aggregate demand and their shares in the total. ${ }^{3}$ The starting point is the national income identity:

$$
Y=C+I+X-M,
$$

where $C$ and $I$ include both public and private consumption and investment, respectively. In ex-post growth terms:

$$
g_{y}=g_{c}(C / Y)+g_{i}(I / Y)+g_{x}(X / Y)-g_{m}(M / Y) .
$$

The sum total of the last two items is defined as the contribution of net exports to GDP growth. Growth is considered to be driven by domestic demand if the contribution of consumption plus investment exceeds that of net exports. The latter can be positive even when there is a trade deficit provided that exports are growing fast enough relative to imports.

This framework cannot correctly distinguish between the contributions of domestic demand and exports to growth and help in assessing the vulnerability of an economy to export shocks because it fails to link imports to components of aggregate demand. It underestimates the contribution of exports and overestimates the contribution of domestic demand to growth because all imports are deducted from exports even though they are used, in part, for domestic consumption and investment. What the term $\left[g_{x}(X / Y)-g_{m}(M / Y)\right]$ can at most describe is the ex-post contribution of trade to growth. On the other hand, the term $g_{x}(X / Y)$ overestimates the contribution of exports to growth because it neglects the import (foreign value-added) contents of exports. With correct accounting, income (valueadded) generated by domestic demand would be lower by the import contents of consumption and investment, and income generated by exports would be lower by its own import content, not by the amount of total imports.

Let $\alpha, \beta$ and $\delta$ denote import intensities of consumption, investment and exports, respectively, so that:

$$
M=\alpha C+\beta I+\delta X,
$$

where the terms on the right-hand side of Equation 3 give imports that go directly and indirectly into consumption, investment and exports, respectively. In a special case where import intensities are all equal $(\alpha=\beta=\delta$ ), they will be given by $m /(1+m)$, where $m=M / Y$.

The import content of consumption has two parts: imported final consumer goods and

\footnotetext{
${ }^{3}$ For an application, see ADB (2005).

(C)2011 The Author

China \& World Economy $\mathbb{C} 2011$ Institute of World Economics and Politics, Chinese Academy of Social Sciences
} 
imported inputs into domestic production of consumables. Similarly, the import content of investment includes imported capital goods plus imported intermediate inputs into domestic investment. For exports, a distinction can be made between domestically produced exports and re-exports. The latter is defined as exports of imported goods after no (or virtually no) further domestic processing and, hence, emphasizes the role of the economy as a distributor or trader, rather than as a producer. However, the distinction is not always clear-cut and there are no generally accepted criteria for re-exports even though a number of countries report them as a different category of exports based on their own definitions. ${ }^{4}$

Using Equation 3 in Equation 1 will give, in growth terms:

$$
g_{y}=g_{c}(1-\alpha)(C / Y)+g_{i}(1-\beta)(I / Y)+g_{x}(1-\delta)(X / Y),
$$

where $(1-\delta) X$ gives exports measured in value-added terms (or value-added exports, VAX). It includes value-added generated in sectors producing exportables (i.e. direct valueadded) and in sectors supplying inputs to exports (indirect value-added). Similarly, $(1-\alpha) C$ and $(1-\beta) I$ are total domestic value-added generated for consumption and investment, respectively.

Import intensities are susceptible to change over time along with changes in consumer preferences, technology and the structure of production. Over shorter periods, exchange rate fluctuations can lead to sizeable changes in import intensities and, hence, the share of imports in GDP by altering the relative demand for foreign and domestically produced goods. However, when import intensities of different components of demand are different, changes in the composition of aggregate demand will alter total imports without any change in the level of income.

Although improving significantly over the traditional net-export accounting, the decomposition in Equation 4 does not provide accurate information about the contribution of exports to growth because it ignores the impact of exports on domestic demand. To account for all such interdependencies, including the impact of domestic demand, notably investment, on exports, one would no doubt need a fully fledged macroeconomic model, allowing for lags in the interactions between domestic components of demand with imports and exports. ${ }^{5}$ For the issue at hand here attention will only focus on the multiplier. A higher level of exports raises domestic consumption through its impact on income, setting the multiplier to work. In this process, imports also rise depending on the import intensity of

\footnotetext{
${ }^{4}$ For a discussion of definition, identification and measurement of re-exports and empirical evidence, see Roos (2006) and Mellens et al. (2007).

${ }^{5}$ For a discussion of the two-way relationship between investment and exports, or the investment-export nexus, see Akyüz (2009).
} 
consumption, dampening the overall impact of export growth on income.

Let $C=c Y$, where $c$ is the average propensity to consume. Then, the overall contribution of exports to GDP growth will be given by:

$$
g_{y / x}=g_{x}[(1-\delta)(X / Y)] \psi
$$

where $\psi=1 /[1-c(1-\alpha)]$, that is, the import-adjusted multiplier. Equation 5 incorporates both the indirect impact of import-adjusted exports on income and its indirect impact through consumption. ${ }^{6}$

\section{Import Content of Exports}

\section{Recent Trends}

The pursuit of export-led growth, trade liberalization and rapid spread of international production networks over the past two decades have resulted in significant increases in import contents of production and consumption almost everywhere, but most visibly in DEE. In particular, the increased use of imported inputs for exports has become a key feature of what is known as vertical specialization, whereby the production sequence of a good involves at least two countries and the good-in-process crosses at least two borders before reaching the final user (Hummels et al., 2001).

Greater participation of DEE in international production networks in manufactures has generated not only a rapid growth in their exports, but also in imports as inputs into their production. Consequently, increased manufactured exports of DEE have not always been matched by commensurate increases in domestic manufacturing value-added (UNCTAD TDR, 2002, 2003). From the late 1980s onwards, total manufacturing exports increasingly exceeded total manufacturing value-added in several DEE closely participating in international production networks, such as Hong Kong, Malaysia, Mexico and Singapore, but the opposite was true in G7 countries and some late-industrializers, such as Korea. In fact, some of these DEE, including Hong Kong and Mexico, have seen their shares in world manufacturing exports rising while their shares in world manufacturing value-added have fallen.

Rapidly increasing re-exporting activities is another reason why exports account for an increasingly high share of GDP in many countries. Mellens et al. (2007) report, in a study of

\footnotetext{
${ }^{6}$ Agarwala (2009) is one of the few studies that accounts for the multiplier effect in estimating the contribution of exports to growth in India, assuming that the import content of exports is at most equal to the average of imports in total expenditures. There is no readily available evidence for India to assess whether this assumption is valid.

(C)2011 The Author

China \& World Economy (C2011 Institute of World Economics and Politics, Chinese Academy of Social Sciences
} 
10 economies, that re-exports have grown faster than domestically produced exports. Reexports are the main reason why exports exceed GDP in several entrepot economies. They account for more than 50 percent of total exports in Singapore and approximately 95 percent of total exports in Hong Kong. However, re-exporting is not confined to small entrepot economies operating as regional or global distributors of certain electronics. According to Mellens et al. (2007), more than half of Dutch manufacturing exports consist of re-exports. The emergence of China is found to have contributed to the role of the Netherlands as the European distribution centre, whereby two-thirds of Dutch imports from China are reexported (Suyker, 2007).

In DEE, recent increases in imports have been driven more than just the growth of production facilities linked to global networks or re-exports. Rapid liberalization of trade and foreign investment over the past two decades has also resulted in increased import intensity of goods and services produced to supply domestic markets. In general, however, import-intensity of exports tends to be much higher than that of domestic demand, not only because export sectors are increasingly linked to global production chains, but also because non-tradable services account for a large proportion of private consumption. For the same reason, the import intensity of investment also exceeds that of domestic consumption, particularly in countries with underdeveloped capital goods industries.

\section{Empirical Evidence}

The estimation of import intensities requires allocation of imports to all expenditure categories on the basis of detailed input-output tables. ${ }^{7}$ There are several studies on advanced economies, often drawing on the OECD input-output database. Statistics and other government offices in a few countries, including the Netherlands and, more recently, Canada, France and Denmark, have been using input-output tables to estimate the contributions of domestic demand and exports to growth based on adjustments for import contents.

Kranendonk and Verbruggen (2008a,b) provide estimates for import intensities for a number of eurozone economies and the USA, using the cumulated production structure matrices obtained by eliminating domestic intermediary demand in input-output tables. These estimates are carried out for four categories of effective demand: private consumption, government consumption, investment and exports. Their findings reveal several features worth noting. First, for the eurozone countries taken together and for most countries individually, the import intensity of exports is greater than the import intensities of all components of domestic demand. Second, exports still account, directly and indirectly, for

\footnotetext{
${ }^{7}$ It should be noted that estimated import intensities might not be reliable when the input-output data are not sufficiently detailed (see Hummels et al., 2001; NRC, 2006). 
less than half of total imports. Third, investment is more import-intensive than private consumption, but because the latter accounts for the chunk of domestic demand (some 60 percent of GDP), approximately one-third of total imports go, directly and indirectly, into private consumption. ${ }^{8}$ Fourth, import intensity of public consumption is lower than the import intensities of other components of demand.

In these estimates, differences in the contribution to growth between the conventional accounting based on net-exports and the import-adjusted method are striking. Using conventional accounting, the contribution of exports to growth in the sample of European countries was negative in 2005, whereas the import-adjusted method attributes almost one-third of GDP growth to exports in that year. Accordingly, the contributions of domestic consumption and investment to growth are much lower than those estimated by conventional accounting.

Estimates of import intensities of components of domestic demand based on input"Coutput data are not available for DEE. Much of the work for DEE has concentrated on vertical specialization and the import contents of exports. One of the first studies in this area (Hummels et al., 2001) included a few DEE, namely, Korea, Taiwan and Mexico, alongside 11 advanced economies, using the OECD input-output database and national input-output tables. For this sample of countries/economies, the average share of foreign value-added in exports was found to be approximately 21 percent in 1990, rising to 23 percent in 1995 . Estimates were then extended to world trade as a whole under certain assumptions for the countries/economies lacking comparable input-output data: for East Asian DEE (China, Hong Kong, Indonesia, Malaysia, Singapore and Thailand), the import content of exports (excluding transit shipment) was assumed to be 25 percent in 1970 and 35 percent in 1995 . For the world economy as a whole, the foreign value-added content of exports, excluding transit shipments or re-exports, is estimated to have increased from 20 percent in 1970 to approximately 30 percent in 1995 . For Korea and Taiwan, import intensities of exports for the mid-1990s were found to be approximately 30 and 40 percent, respectively, with little increases from previous decades.

Similar estimates of domestic and foreign contents of exports are provided for a number of advanced and developing economies by Miroudot and Ragoussis (2009) and Johnson and Noguera (2009). The findings of the latter study for selected Asian economies are summarized in Table $1 .^{9}$ The figures exclude re-exports. It is notable that the domestic value-

${ }^{8}$ Claus and Li (2003) also find, for a number of countries, that the import content of consumption is lower than that of both exports and investment.

${ }^{9}$ Johnson and Noguera (2009) provide estimates based on the same method as in Hummels et al. (2001) and a variant of that method, which produces slightly different estimates. The numbers in Table 1 are the averages of the two. 
Table 1. Domestic Content of Asian Exports: 2001

\begin{tabular}{l|c}
\hline Country/economy & $\%$ \\
\hline Japan & 88 \\
\hline India & 87 \\
\hline China & $80\left(66^{\mathrm{a}}\right)$ \\
\hline Indonesia & 79 \\
\hline Hong Kong & 76 \\
\hline Korea & 65 \\
\hline Chinese Taiwan & 64 \\
\hline Malaysia & 63 \\
\hline Thailand & 60 \\
\hline Vietnam & 56 \\
\hline Philippines & 42 \\
\hline Singapore & 35 \\
\hline
\end{tabular}

Source: Johnson and Noguera (2009).

N ote: adjusted for processing trade.

added contents of exports of Indonesia, Malaysia and Thailand are similar to or higher than those of economies at a higher level of industrialization: Korea and Taiwan. This is mainly due to a high share of commodities in the total exports of the former economies, which contain higher domestic value-added than manufactured exports. ${ }^{10}$ In Chinese Mainland, the domestic value-added content of exports is also higher than that of Korea and Taiwan, but, as discussed here, this is no longer the case when estimates are adjusted for export processing.

Estimates given in several studies for foreign and domestic contents of Chinese exports differ quite significantly according to the data and the method used. It is generally agreed that the vertical specialization framework developed by Hummels et al. (2001) is not appropriate for countries that engage actively in processing exports, such as China, Mexico and Vietnam. In such cases, the assumption that intensity in the use of imported inputs is the same between non-processing and processing exports or between production for domestic sales and production for exports would result in an underestimation of import contents of exports. Therefore, it is necessary to generate and use separate input-output tables for export processing sectors, rather than relying on the unified official input-output

\footnotetext{
${ }^{10}$ In a sample of 40 countries, the average import content of agricultural and mining exports in 2005 was less than 20 percent, compared to more than 30 percent for most manufactured exports (see Miroudot and Ragoussis, 2009). Johnson and Noguera (2009) also find that value-added to export ratios are substantially higher in agriculture, natural resource and service sectors than in manufacturing. See Hummels et al. (2001) for a similar conclusion for the earlier period.
} 
table. ${ }^{11}$

Table 2 contains estimates for import contents of Chinese exports reached by various studies using single and/or separate input-output tables for non-processing and processing exports. The average import content of exports is much higher when separate input-output tables are used. Processing exports accounted for approximately 55-60 percent of total Chinese exports in the first half of this decade (Feenstra and Hong, 2007; Koopman et al., 2008). Their import content is several times that of non-processing exports: in 2002 it was approximately 75 percent against 11 percent. ${ }^{12}$ Import content is particularly high, over 80 percent, in sectors processing high-end manufactures, such as electronics compared to low-skill exports. Foreign firms are active in export processing and have particularly higher import content in their exports than do domestic firms. Wholly foreign-owned enterprises exhibit the lowest share of domestic value-added, followed by joint venture companies (Koopman et al., 2008).

On some accounts, domestic value-added contents of Chinese exports have been rising as a result of growing supply capabilities and technological upgrading. The rising trade surplus brought about by a slowdown in imports relative to exports after 2004 is often interpreted as a sign of a weakening of the link between exports and imports, and this is supported by some econometric evidence (Cui and Syed, 2007). However, studies based on input-output data covering the period from mid-1990s to 2006 do not generally show a

Table 2. Import Intensity of Chinese Exports (\%)

\begin{tabular}{l|c|c|c}
\hline Study & Year & Single IO $^{\mathbf{a}}$ & Separate IO $^{\mathbf{b}}$ \\
\hline Chen et al. $(2004)$ & 1995 & - & 45.5 \\
\hline Koopman et al. $(2008)$ & 1997 & 17.6 & 47.7 \\
\hline Dean et al. (2008) & 1997 & 17.9 & 47.7 \\
\hline Johnson and Noguera (2009) & 2001 & 20.0 & 34.0 \\
\hline Ping (2005) & 2002 & 21.0 & - \\
\hline Koopman et al. (2008) & 2002 & 25.1 & 46.1 \\
\hline Dean et al. (2008) & 2002 & 25.4 & 46.1 \\
\hline Chen et al. (2008) & 2002 & - & 53.4 \\
\hline Miroudot and Ragoussis (2009) & 2005 & 0.0 & - \\
\hline Koopman et al. $(2008)$ & 2006 & 26.3 & 49.3 \\
\hline
\end{tabular}

N otes: a Using single input-output (IO) table for domestically produced and processing exports. ${ }^{b}$ Using separate input-output tables for domestically produced and processing exports.

\footnotetext{
${ }^{11}$ In China, processing exports refer to a special category of goods produced by assembling and/or processing intermediate inputs that are exempted from tariffs because the final products are sold only in foreign markets. Chen et al. (2004) was the first study using separate input-output tables for nonprocessing and processing exports in China. For a comparison of the two methods and estimates based on them, see Koopman et al. (2008) and Dean et al. (2008).

${ }^{12}$ See Koopman et al. (2008). Chen et al. (2008) estimate, for the same year, similar import content for processing exports but a higher figure (37 percent) for non-processing exports.
} 
declining trend in the foreign content of Chinese exports. ${ }^{13}$ This might have changed in more recent years for two main reasons. First, the share of processing exports has continued to fall and was below 50 percent of total exports in 2008 ( $\mathrm{Li}$ and Fung, 2009). This should bring a decline in the average import intensity of Chinese exports because non-processing exports have higher domestic value-added contents. Second, in processing exports, China appears to have been shifting from simple assembly of foreign parts and components towards operations with greater domestic inputs, thereby raising their domestic valueadded contents (Cui, 2007).

The estimates made for the first half of the 2000s show that the average foreign valueadded content of Chinese exports was between 40 and 50 percent. A very large proportion of foreign content of exports consisted of imported parts and components directly used in sectors producing exportables. This proportion was particularly high in export processing sectors while in non-processing exports the shares of direct and indirect import contents were similar. Close to two-thirds of domestic value-added contents of non-processing exports were generated in other sectors supplying inputs, whereas for processing exports direct and indirect value-added contents were broadly equal.

Chinese exports to the USA are found to have greater import contents than its exports to the rest of the world, in large part because a very high proportion of exports to the USA, approximately 78 percent in 2002, are processing exports. In 2002, the foreign value-added content of exports to the USA was approximately 63 percent, compared to less than 50 percent for total Chinese exports. ${ }^{14}$ By contrast, US exports to China have very high domestic value-added content (approximately 87 percent in the same year) and very low foreign value-added content (13 percent). As a result, although in gross value terms the bilateral trade surplus of China with the USA was estimated to be some US\$172bn in 2005, in value-added terms this figure reduces to less than US\$40bn. In other words, China's exports to the USA contain large amounts of value-added generated elsewhere, including in its Asian trading partners and even the USA itself (Lau et al., 2006).

A relatively important part of the domestic value-added generated by Chinese exports accrue to foreign firms. This is particularly the case for processing exports where foreign firms are dominant. It is estimated by Lau et al. (2006) that of the total domestic value-added generated by Chinese exports to the USA in 2002, approximately two-thirds went to capital

\footnotetext{
${ }^{13}$ For changes between the mid-1990s and early 2000s, see Chen et al. (2008). Preliminary estimates for 2006 by Koopman et al. (2008), however, show a steep decline in domestic value-added generated by processing exports, but little change in that generated by non-processing exports.

${ }^{14}$ See Lau et al. (2006). According to Dean et al. (2008), the foreign import content of Chinese exports to the USA was 55 percent, compared to the average foreign content of its total exports of 46 percent.
} 
income, some 18 percent to labor and 14 percent to indirect taxes. Approximately 60 percent of these exports were by foreign firms, including firms from the USA. Even if it is assumed that such firms shared only in the direct capital income, it can be estimated that an additional 7 percent of the value of total Chinese exports to the USA went to foreign firms. As a result, income left in China was no more than one-third of total value of exports to the USA.

\section{To What Extent is Growth in China Export-led?}

\section{Recent Experience}

The evidence examined above shows that Chinese exports have relatively high import contents. On average, domestic value-added generated by exports is not much more than half of their gross value and the rest is accounted for by foreign value-added, mainly imported parts and components and other intermediate inputs.

However, even in value-added terms, the share of Chinese exports in GDP (i.e. the VAX/GDP ratio) is very high, in the order of 18-22 percent, of which 7-9 percentage points consist of direct value-added generated in sectors producing exportables. This is much higher than what would be expected for an economy of its size; it is higher than even the conventionally measured exports to GDP ratio in the USA, Japan and Brazil. The main reason is the phenomenal growth of its exports since the beginning of the decade, at a rate of some 25 percent per annum, more than three times the domestic consumption and twice the domestic investment, which took the exports to GDP ratio of 36 percent before the outbreak of the global crisis in 2008 (Tables 3 and 4).

Table 4 uses the estimates given by Koopman et al. (2008) in calculating VAX/GDP ratios and direct and indirect value-added contents of exports as a proportion of GDP. ${ }^{15}$

Table 3. Growth of Real GDP and Its Components in China (\%)

\begin{tabular}{c|c|c|c|c|c}
\hline & GD P & Consumption & $\begin{array}{c}\text { G ross capital } \\
\text { formation }\end{array}$ & Exports & I mports \\
\hline 2002 & 9.1 & 7.4 & 13.2 & 29.4 & 27.4 \\
\hline 2003 & 10.0 & 6.6 & 17.2 & 26.8 & 24.9 \\
\hline 2004 & 10.1 & 7.1 & 13.4 & 28.4 & 22.7 \\
\hline 2005 & 10.4 & 7.3 & 9.0 & 24.3 & 11.4 \\
\hline 2006 & 11.6 & 8.4 & 11.1 & 23.8 & 15.9 \\
\hline 2007 & 14.2 & 10.8 & 14.2 & 20.0 & 14.2 \\
\hline 2008 & 9.6 & 8.5 & 11.0 & 8.6 & 5.1 \\
\hline 2009 & 9.1 & 8.5 & 19.8 & -10.4 & 4.3 \\
\hline
\end{tabular}

Source: World Bank, CQU (various issues).

\footnotetext{
${ }^{15}$ In Table 4, estimates for foreign and domestic contents for 2006 are also used for calculating the VAX/ GDP ratio for 2007 .
} 
Table 4. Exports, Imports and Income in China (\%)

\begin{tabular}{l|c|c|c}
\hline & $\mathbf{2 0 0 2}$ & $\mathbf{2 0 0 6}$ & $\mathbf{2 0 0 7}$ \\
\hline$X / G D P$ & 22.4 & 36.5 & 36.0 \\
\hline$V A X / G D P$ & 12.1 & 18.5 & 18.3 \\
\hline Direct & 4.5 & 7.0 & 7.0 \\
\hline Indirect & 7.6 & 11.5 & 11.3 \\
\hline$T B / G D P$ & 3.0 & 8.2 & 9.3 \\
\hline$M / G D P$ & 20.3 & 29.8 & 28.3 \\
\hline$M_{x} / M$ & 50.7 & 60.2 & 62.1 \\
\hline$I G / M$ & 72.6 & 74.4 & 75.2 \\
\hline
\end{tabular}

Sources: IMF IFS, UN Comtrade and Koopman et al. (2008)

N ote: X, exports; GDP, gross domestic product; VAX, exports measured in value-added; TB, trade balance; M, imports; Mx, imports used for exports; IG, imports of intermediate goods.

The increase in VAX/GDP between 2002 and 2007 reflects mainly the increased share of exports in GDP as conventionally measured rather than declines in their foreign valueadded contents. The VAX/GDP ratio exceeds by a wide margin the ratio of trade surplus to GDP because not all imports are used for producing exportables. Some 60 percent of total imports and over 80 percent of intermediate goods imports are used, directly and indirectly, for exports and the rest for domestic consumption and investment.

According to some estimates, the contribution of value-added exports to GDP in China is much smaller than the figures given in Table 4. Anderson (2007a) puts it at only 7.7 percent; that is, less than half of the VAX/GDP ratio in Table 4. However, this estimate by Anderson (2007a) is reached by deducting from exports not only "the associated import content" in sectors producing exportables but also "input purchases from other sectors." It thus excludes the indirect domestic value-added contents of exports which, as noted, exceed direct domestic value-added by a large margin. Indeed, it comes very close to the share of direct value-added content of exports in GDP estimated on the basis of input"Coutput tables. More importantly, it is below the ratio of trade surplus to GDP. Therefore, even if it is assumed that all imports are used for exports and none for domestic consumption and investment, the value-added generated would still be higher than 7.7 percent of GDP. ${ }^{16}$

Table 5 compares the estimates for the contribution of exports to growth in China over

\footnotetext{
${ }^{16}$ These considerations are also valid for the findings of another study, He and Zhang (2008), according to which the domestic value-added content of exports was 15 percent in 2002. This would imply a VAX/ GDP ratio of approximately 3 percent. This is more or less equal to the trade-balance ratio in that year (see Table 4), implying that consumption and investment use little or no imports. The study uses the methodology developed by Koopman et al. (2008) for separation of imports for processing and nonprocessing exports and the data from the same 2002 input-output table, but does not explain why it reaches significantly different estimates.
} 
2004-2009 made according to conventional accounting in Equation 2 based on net exports with those based on the adjustment of exports and domestic demand for their import contents. The latter estimates take the import content of exports to be 50 percent. This is on the high end of various estimates based on input-output data discussed above, particularly for the more recent years. Therefore, the figures in the last column of Table 5 should be interpreted as the minimum contributions of exports to growth. Even then they exceed the estimates based on net exports by a large margin for the years preceding the crisis. According to conventional estimates, from 2004 until 2008, net exports accounted for, on average, no more than 15 percent of growth, while the average contribution of exports reached onethird when import contents of exports and domestic demand are both taken into account. Therefore, in China, the dependence of growth on exports has been quite significant, despite a very high import content of exports.

The figures in Table 5 do not include the multiplier effect of exports on consumption and income. To account for this, it is necessary to estimate the import content of consumption ( $\alpha$ in Equation 5). This is not directly available but on some reasonable assumptions it can be estimated to be less than 8 percent. ${ }^{17}$ This implies that during 2004-2007, over 60 percent of total imports were used, directly and indirectly, for exports and under 15 percent for domestic consumption. Even for a lower import content of exports, say $\delta=0.40$, the import intensity of domestic consumption would not be much higher, approximately 10 percent, and imports used for domestic consumption and investment together would barely reach

\section{Table 5. Contributions of Domestic Demand and Exports to Growth in China (\%)}

\begin{tabular}{l|c|c|c|c|c}
\hline \multirow{2}{*}{ Y ear } & \multirow{2}{*}{ GDP (\%) } & \multicolumn{2}{|c|}{ Conventional } & \multicolumn{2}{c}{ I mport-adjusted } \\
\cline { 3 - 6 } & & D omestic demand & N et exports & D omestic demand & Exports \\
\hline 2004 & 10.1 & 9.6 & 0.5 & 6.3 & 3.8 \\
\hline 2005 & 10.4 & 8.1 & 2.3 & 6.7 & 3.7 \\
\hline 2006 & 11.6 & 9.8 & 1.8 & 7.5 & 4.1 \\
\hline 2007 & 14.2 & 11.7 & 2.5 & 10.6 & 3.6 \\
\hline 2008 & 9.6 & 8.8 & 0.8 & 8.0 & 1.6 \\
\hline 2009 & 9.1 & 12.8 & -3.7 & 11.0 & -1.9 \\
\hline
\end{tabular}

Sources: Conventional Accounting: for 2004-2006 from ADB (2009) and for 2007-2009 from World Bank CQU (November 2010).

\footnotetext{
${ }^{17}$ Once the import content of exports is known, the import intensity of domestic demand $(\eta)$ can be obtained from $Y=D(1-\eta)+X(1-\delta)$, where $D$ is aggregate domestic demand $(C+I)$. For $\delta=0.50$, it is approximately 11 percent. We assume, on the basis of the estimates for several advanced economies discussed above, that the import intensity of consumption $(\alpha)$ is no more than half of that of investment ( $\beta$ ). For $\delta=0.50, \eta=0.11$ and $\alpha=\beta / 2$, the import intensity of consumption will come to less than 8 percent.

(C)2011 The Author

China \& World Economy (C2011 Institute of World Economics and Politics, Chinese Academy of Social Sciences
} 
50 percent of the total. These figures are quite low compared to those in advanced economies, particularly because the share of goods in consumption is higher and that of services is lower in China, and goods have higher import intensity than services. They suggest that the Chinese economy is pretty closed to imports, except for exports and export-oriented investment.

With these values of import-intensity of consumption, the import-adjusted multiplier $(\psi \text { in Equation 5 })^{18}$ is between 1.5 and 1.6, implying that approximately 50 percent of GDP growth before the outbreak of the crisis was due to exports, including through its impact on consumption. However, there are reasons to expect a lower multiplier from incomes earned in export sectors than the average for the economy as a whole. As noted above, some twothirds of value-added in export sectors accrue to gross profits and less than one-fifth goes to wages. The share of wages in export sectors is much lower and that of profits much higher than in the economy as a whole (see Figure 1). Because the propensity to consume from wages is significantly higher than the propensity to consume from profits and because profits in export sectors partly go to foreign firms, income earned in these sectors can be expected to generate proportionately less consumption than income earned in the rest of the economy. Consequently, the multiplier would be smaller. However, even if one were to apply half the average consumption ratio, the multiplier would still be approximately 1.2 , implying that approximately 40 percent of growth before the crisis was due to exports.

\section{Figure 1. Wages, Profits and Private Consumption}

\section{(As a Percentage of GDP)}

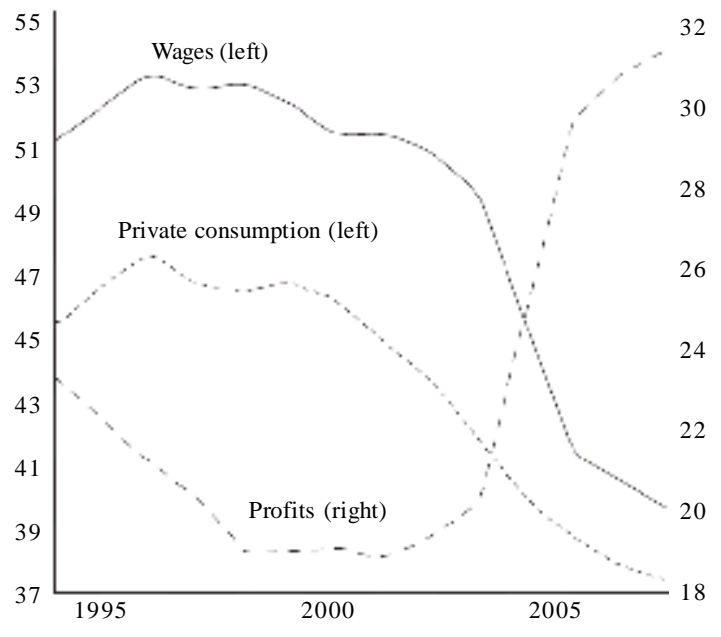

\footnotetext{
${ }^{18}$ Here, the share of private consumption in GDP rather than total consumption is used to estimate the import-adjusted multiplier.
} 
According to these estimates, in China, a 10-percent growth in exports would generate at least 2 percent growth in GDP, including through its impact on domestic consumption. If account is taken of the impact on investment, this figure would be higher. An econometric study taking into consideration all spillovers to domestic demand, including the knock-on effect on investment, puts it at 2.5 percent (Cui et al., 2009). A similar figure is suggested by income multipliers estimated by ESCAP (2010) on the basis of the Oxford Economic Forecasting model. ${ }^{19}$ Therefore, if spillovers from exports to both consumption and investment are accounted for, it would not be an exaggeration to conclude that approximately 50 percent of Chinese growth during 2004-2007 came from exports.

\section{Chinese Vulnerability to a Slow down in Exports}

These findings suggest that the Chinese economy is highly vulnerable to export shocks, as seen during the recent downturn in the world economy. The growth rate of Chinese exports and their contribution to GDP growth declined sharply in 2008, before becoming negative in 2009 (Table 5). There was a swing of some 6 percentage points in the contribution of exports to growth in 2009 from 2004-2007, even without accounting for spillovers to domestic demand. This is only partly offset by faster growth of domestic demand. Despite a massive fiscal package of some US\$600bn or 15 percent of GDP and aggressive monetary easing and rapid credit expansion, GDP growth in 2009 is estimated to have remained some 2 percentage points below the 2004-2007 average.

This heavy dependence on exports is the outcome of underconsumption. From the beginning of the decade until the global crisis in 2008, Chinese investment grew faster than consumption, and the demand gap was filled by rapidly growing exports (Table 3 ). The share of private consumption in GDP fell from over 50 percent in the 1990s to approximately 36 percent on the eve of the crisis, whereas that of investment rose to 45 percent (Figure 1). ${ }^{20}$ The recent stimulus package has pushed the investment rate further, close to 50 percent of GDP, and aggravated the problem of excess capacity that had pervaded several sectors and increased the dependence of growth on exports. A very large proportion of the fiscal package has been allocated to investment in infrastructure, with less than 20 percent assigned to social spending (Li, 2009). Policies designed to revive real estate demand and an unprecedented growth in mortgage lending to households have created a bubble in the

\footnotetext{
${ }^{19}$ The export multiplier shows that every US\$1 loss of exports in China would cut GDP by US $\$ 0.66$. Using the average ratio of exports to GDP over 2004-2007, this would imply that a 10-percent growth in exports would generate approximately 2.3 percent growth in GDP, including spillovers to domestic demand.

${ }^{20}$ On the evolution of investment and consumption, see World Bank CQU (various issues) and Aziz and Dunaway (2007). 
property market, with real estate investment growing by close to 40 percent. Although private consumption levels were maintained, thanks to several incentives, particularly for car purchases, this did not provide much impetus to offset the sharp decline in exports. The increase in investment is estimated to have contributed between 80 and 90 percent of growth in 2009 (Hung, 2009; Wolfe and Ziemba, 2009).

As the impact of the stimulus package fades away, capacity utilization and growth will again depend on a rapid expansion of exports, because the share of consumption is not expected to register a significant increase in the immediate period ahead. Although Chinese exports started to recover rapidly at the end of 2009 and are expected to record double-digit growth for 2010, projections for 2011-2012 suggest a sharp slowdown to single digit figures (World Bank CQU, November 2010). Accordingly, growth is expected to remain below not only the rates attained during pre-crisis years, but also during 2008-2009.

Can China go back to export-led growth over the medium term as the world economy recovers from the current crisis? In the past decade, China's exports rose twice as fast as world trade and its share in world merchandise trade doubled, overtaking the USA and, more recently, Germany to become the world's number one exporter. A return to trend growth of some 10 percent per annum based on exports would mean continued increases in its penetration of markets abroad and its share in world trade. If growth in advanced economies, which constitute the main markets of China, remain sluggish, as suggested by most medium-term projections (e.g. IMF WEO, October 2010), the required increase in China's share in world markets will be even greater.

A return to "business as usual" with the USA continuing to consume beyond its means and absorbing Chinese exports by issuing growing amounts of dollar liabilities is not a sustainable option: it is a recipe for deeper international monetary and financial instability. Rather, the USA needs to live within its means and to shift from consumptionled to export-led growth, as it now appears to be determined to do (Akyüz, 2010). Under these conditions, an aggressive export push by China in the markets of advanced economies or other developing countries is likely to meet strong resistance, creating conflict in the trading system. ${ }^{21}$ Indeed, China has already encountered adverse reactions not only from

\footnotetext{
${ }^{21}$ In a scenario by Guo and N'Diaye (2009) to achieve a growth of 8.5 percent per annum over 2011-2020, Chinese real exports would need to grow by 14.5 percent per annum, more than twice the projected growth in the world trade volume, and its current account surplus would reach 15 percent of GDP. Its share in world exports would rise to 15 percent, requiring large gains in markets for steel, ship building and machine tools. In the view of these authors, the main impediment to such a growth path would be the difficulties in lowering prices to the extent needed for gaining market shares, rather than problems associated with growing trade imbalances.
} 
the USA and the EU, but also from some DEE, including India and Indonesia. If, however, it cuts the rate of expansion of its exports to a more acceptable level, say to 10 percent, then, without a fundamental change in the pace and pattern of domestic demand, its growth might barely reach 7 percent. ${ }^{22}$ Growth might drop a lot more if the credit-driven investment bubble bursts, exposing bad loans and giving rise to difficulties for overstretched banks and, eventually, a financial crisis. ${ }^{23}$

\section{The way out}

A solution to this dilemma could be to lower the foreign content of exports so as to enhance their contribution to growth. This would require technological upgrading and substitution of high-technology imported parts and components with domestic production and a shift from processing to non-processing exports. Such a transformation has been taking place since the early years of the decade but there has been no significant decline in the average import content of exports, possibly because of increased vertical specialization in nonprocessing exports. Indeed, such a process would take a long time to have its effects felt on domestic contents of exports. Marginal declines in import contents cannot offset a sharp deceleration in the pace of exports so as to sustain rapid growth. Besides, such a process would imply continued growth of a Chinese trade surplus, thereby aggravating global imbalances.

If the aim is to maintain pre-crisis growth rates of 10 percent or more, the solution is naturally to raise domestic consumption much faster than has been the case so far. The estimates above suggest that for every 10-percentage point decline in export growth, private consumption would need to expand by at least an additional 5 percentage points to keep growth unchanged. ${ }^{24}$ This means that if exports keep pace with income, consumption would need to grow faster than GDP and investment would need to grow slower than GDP. Thus, returning to a path of some 10-percent growth would require reversing the downward trend in the share of private consumption and the upward trend in the share of investment in GDP.

The coexistence of a growing current account surplus with an exceptionally high rate of investment is a clear symptom of underconsumption. One reason for this is high

\footnotetext{
${ }^{22}$ Even 10-percent real export growth is well above the 6.4 percent world trade volume growth assumed in the IMF Medium-Term Baseline Scenario; see IMF WEO (October 2009).

${ }^{23}$ Before the outbreak of the crisis the bursting of the asset (property and stock) bubbles was expected to reduce growth in China by approximately 2 percentage points (see Chancellor, 2008).

${ }^{24}$ This is because consumption generates more domestic value-added than exports: its import content $(\alpha)$ is lower than the import content of exports $(\delta)$, and its share in GDP is approximately the same as the share of exports, as conventionally measured.

(C)2011 The Author

China \& World Economy (C2011 Institute of World Economics and Politics, Chinese Academy of Social Sciences
} 
precautionary savings by households because of inadequate public provision of some basic needs, including health care, housing and education. ${ }^{25} \mathrm{~A}$ more important reason is the low share of household income and a very high share of corporate profits and savings in GDP. In 2008, household income accounted for less than 60 percent of GDP, down from two-thirds at the end of the 1990s (Ma and Yi, 2010). As a result, despite a high propensity to save, household savings as a proportion of GDP are not much higher than those in other DEE where household share in GDP is higher. They have varied around 22 percent of GDP during 2005-2008, up from 20 percent at the end of 1990s. This is broadly the same as the ratio of household savings to GDP in Malaysia in the 1980s and in India since the middle of the decade. However, at more than 50 percent of GDP, China's national savings rate exceeds that of India's by a large margin because of significantly higher corporate retentions: over 20 percent of GDP compared to 10 percent in India. Chinese corporate profits and savings are also much higher than those in late industrializers in Asia, including Japan, 15 percent of GDP during the 1960s, and Taiwan and Korea, 12 and 8 percent of GDP, respectively, in the first half of the 1980s. ${ }^{26}$

The disparity between consumption and investment and the consequent dependence on foreign markets is largely the outcome of the imbalance between wages and profits. Wages in China constitute a very large proportion of household income because government transfers and investment income, including dividends, are very small. ${ }^{27}$ Despite registering impressive increases, wages have lagged behind productivity growth and their share in value-added has been declining. ${ }^{28}$ Since the early years of the decade, labor productivity in manufacturing has grown by some 20 percent per annum, while nominal wage increases have been under 15 percent and real wage increases even lower. Profits rose faster than sales and the share of labor cost in total gross output in mining, manufacturing and utilities fell from 11.5 percent in 2002 to 7.1 percent in 2006; for the economy as a whole, the share of wages in GDP fell to approximately 40 percent after fluctuating between 50 and

\footnotetext{
${ }^{25}$ On official estimates, household savings as a proportion of disposable income were around 40 percent in 2008, up from 30 percent at the turn of the decade (Ma and Yi, 2010), while some survey-based estimates for 2008 give a lower figure, around 28 percent, compared to 32 percent in India (Prasad, 2009).

${ }^{26}$ For household and corporate savings in early industrializers, see Akyüz and Gore (1996) and UNCTAD TDR (1997). Estimates of corporate savings as a percentage of GDP differ widely. According to Ma and Yi (2010), they are lower than the share of household savings, whereas the opposite is the case in the estimates provided by Prasad (2009) and Anderson (2007b).

${ }^{27}$ According to Aziz and Cui (2007), in 2005 investment income accounted for 3 percent of households' disposable income, while government transfers made up no more than 0.5 percent of GDP.

${ }^{28} \mathrm{On}$ the recent behavior of labor productivity, profits and wages and consumption, see Kim and Kuijs (2007) and World Bank CQU (August 2006 and February 2007).
} 
55 percent in the 1990s. High share of profits in value-added, non-payment of dividends to the government by state-owned enterprises and tax incentives are mentioned among the main reasons for rapid increases in corporate retentions and investment (Kuijs, 2005; World Bank CQU, August 2005; Aziz and Dunaway, 2007; Yu, 2007). The downward trend in the share of wages in GDP is the main reason for the declines in the shares of household incomes and private consumption in GDP (Figure 1).

It is true that success in industrialization crucially depends on the pace of capital accumulation, which, in turn, depends very much on the volume of profits and the extent to which they are used for investment. High corporate retention and a dynamic profit-investment nexus, rather than high household savings, have been the key distinguishing components of successful industrialization in East Asia (Akyüz and Gore, 1996). China is not an exception in this respect. However, unlike China, most late industrializers, particularly Japan and Korea, did not rely on cheap labor and cheap currency. In these countries, wages and private consumption grew in tandem with productivity and underpinned the expansion of productive capacity by providing a growing internal market. Private consumption as a proportion of GDP in the newly-industrialized economies and Japan have constantly exceeded that of China since the mid-1980s and the gap has risen to 18 percentage points in the present decade. $^{29}$

In view of bleak export prospects, a return to trend growth in China crucially depends on a sizeable increase in the share of household income in GDP and a corresponding decline in corporate profits, savings and investment. This calls for a higher share of wages in value-added and significantly greater government transfers to households, particularly in rural areas where incomes remain depressed. Greater public spending on social infrastructure in health, housing and education would not only improve social welfare but also serve to reduce relatively high precautionary household savings. These expenditures and income transfers can be financed by dividend payments by state-owned enterprises, thereby simultaneously curbing excessive investment.

A shift from export-led to consumption-led growth would also require significant industrial restructuring. An important part of Chinese exports are specific to foreign markets with little domestic demand. Unlike in the mainstream (neoclassical) theory of production where "factors of production" can be shifted freely among different lines of production to produce different goods and services, in reality, skills, capital equipment and organizational

\footnotetext{
${ }^{29}$ See Hung (2009), who argues that the urban-industry biased development model "is the source of China's prolonged 'limitless' supply of labor, and thus of the wage stagnation that has characterised its economic miracle" (p. 14) and that China's “export competitiveness has been built upon long-term wage stagnation." (p. 18). 
structures are often industry-specific and even product-specific. This means that adjustment in the production structure would depend primarily on reallocation of new investment and skills towards areas that need to expand to meet higher domestic consumption. In this process, state guidance of investment could no doubt play an important role.

\section{References}

ADB (Asian Development Bank), 2005, Asian Development Outlook 2005, Manila: ADB.

ADB (Asian Development Bank), 2009, Asian Development Outlook 2009, Manila: ADB.

Agarwala, Ramgopal, 2009, "On managing risks facing the Indian economy: Towards a better balance between public and private sectors," Mimeo, RIS, India, September.

Akyüz, Yilmaz, 2009, Exchange Rate Management, Growth and Stability: National and Regional Policy Options In Asia, Colombo: UNDP.

Akyüz, Yilmaz, 2010, "Global economic prospects: The recession may be over but where next?" South Centre Research Paper No. 26, Geneva, March.

Akyüz, Yilmaz and Charles Gore, 1996, "The investment-profits nexus in East Asian industrialisation," World Development, Vol. 24, No. 3, pp. 461-70.

Anderson, Jonathan, 2007a, "Is China export-led?" UBS Investment research, Asian Focus, 26 September [online; cited November 2010]. Available from: www.ubs.com/economics.

Anderson, Jonathan, 2007b, "Solving China's rebalancing puzzle," Finance and Development, Vol. 44, No. 3, pp. 32-35.

Aziz, Jahangir and Li Cui, 2007, "Explaining China's low consumption: The neglected role of household income," IMF Working Paper No. 07/181, IMF, Washington, DC.

Aziz, Jahangir and Steven Dunaway, 2007, "China's rebalancing act," Finance and Development, Vol. 44, No. 3, pp. 27-31.

Bergsten, Fred, 2008, “Trade has saved America from recession," Financial Times, 1 July.

Claus, Iris and Kathy Li, 2003, "New Zealand's production structure: An international comparison," New Zealand Treasury Working Paper No. 03/16, September, Wellington, NZ, Treasury.

Chancellor, Edward, 2008, "Bursting Chinese bubble could hurt," Independent Investor, 18 January [online; cited November 2010]. Available from: http://archive.independent-investor.com/stories/ Chinas_bubble__814.aspx?print=true.

Chen, Xikang, Leonard K. Cheng, K. C. Fung and Lawrence J. Lau, 2004, “The estimation of domestic value-added and employment induced by exports: An application to Chinese exports to the United States," Paper presented at the AEA Meeting; January 2005, Boston, MA; mimeo, Stanford University, Stanford, California.

Chen, Xikang, Leonard K. Cheng, K.C. Fung, Lawrence J. Lau, Yunwing Sung, C. Yang, K. Zhu, J. Pei and Z. Tang, 2008, "Domestic value added and employment generated by Chinese exports: A quantitative estimation," Munich Personal RePEc Archive (MPRA) Paper No. 15663 [online; cited November 2010]. Available from: mpra.ub.uni-muenchen.de/15663/. 
Cui, Li, 2007, “China's growing external dependence," Finance and Development, Vol. 44, No. 3, pp. $42-45$.

Cui, Li and Murtaza Syed, 2007, "The shifting structure of China's trade and production," IMF Working Paper No. 07/214, IMF, Washington, DC.

Cui, Li, Chang Shu and Xiaojing Su, 2009, "How much do exports matter for China's growth?" China Economic Issues, 1/09, March, Hong Kong Monetary Authority, Hong Kong.

Dean, Judith, K.C. Fung and Zhi Wang, 2008, "How vertically specialized is Chinese trade?" US International Trade Commission Office of Economics Working Paper No. 2008-09-D. U.S. International Trade Commission, Washington, DC.

The Economist, 2007, “China's economy. How fit is the panda?" 27 September [online; cited December 2009]. Available from: http://www.economist.com/node/9861591? story_id=9861591.

ESCAP, 2010, "Economic and social survey of Asia and the Pacific 2010," Bangkok [online; cited November 2010]. Available from: www.unescap.org.

Feenstra, Robert C. and Chang Hong, 2007, "China's exports and employment," NBER Working Paper No. 13552, National Bureau of Economic Research, Cambridge, MA.

Guo, Kai and Papa N'Diaye, 2009, “Is China's export-oriented growth sustainable?" IMF Working Paper No. 09/172, IMF, Washington, DC.

He, Dong and Wenlang Zhang, 2008, "How dependent is the Chinese economy on exports and in what sense has its growth been export-led?" Working Paper No. 0814, Hong Kong Monetary Authority, Hong Kong.

Hung, Ho-Fung, 2009, “America's head servant? The PRC's dilemma in the global crisis," New Left Review, Vol. 60, November-December. pp. 5-25.

Hummels, David, Jun Ishii and Kei-Mu Yi, 2001, "The nature and growth of vertical specialization in world trade," Journal of International Economics, Vol. 54, No. 1, pp. 75-96.

IMF, World Economic Outlook, various issues, IMF, Washington, DC.

Johnson, Robert C. and Guillermo Noguera, 2009, "Accounting for intermediaries: Production sharing and trade in value added," Mimeo, Dartmouth College, Hanover, NH, USA.

Kim, S-Y, and Louis Kuijs, 2007, "Raw material prices, wages and profitability in China's industry? How was profitability maintained when input prices and wages increased so fast?" World Bank China Research Paper No. 8, World Bank, Beijing.

Koopman, Richard, Zhi Wang and Shangjin Wei, 2008, "How much of Chinese exports really made in China? Assessing domestic value-added when processing trade is pervasive," NBER Working Paper No. 14109, National Bureau of Economic Research, Cambridge, MA.

Kranendonk, Henk and Johan Verbruggen, 2008a, "Decomposition of GDP growth in European Countries," CPB Document No. 158, Netherlands Bureau for Economic Policy Analysis, Hague, the Netherlands.

Kranendonk, Henk and JohanVerbruggen, 2008b, "Decomposition of GDP growth in some European countries and the United States,” De Economist, Vol. 156, No. 3, pp. 295-306.

Kuijs, Louis, 2005, "Investment and saving in China," World Bank Policy Research Working Paper No. 3622, World Bank, Washington, DC.

(C) 2011 The Author

China \& World Economy (C2011 Institute of World Economics and Politics, Chinese Academy of Social Sciences 
Lau, Lawrence J., Xikang, Chen, Leonard K. Cheng, K.C. Fung, J. Pei, Y-W Sung, Z. Tang, Y. Xiong, C. Yang and K. Zhu, 2006, "Estimates of US-China trade balance in terms of domestic valueadded," Stanford Center for International Development Working Paper No. 295, Stanford Centre for International Development.

Li, Xiaochao, 2009, "The steady upturn trend of national economy further strengthened," 22 October, National Bureau of Statistics of China, Beijing.

Li\&Fung, 2009, China Trade Quarterly, November, No. 16, Li\&Fung Research Center, Hong Kong [online; cited November 2010]. Available from: http://www.idsgroup.com/profile/pdf/ lfch_tradequarterly/ChinaTradeQuarterly3Q09_v3.pdf.

Ma, Guonan and Wang Yi, 2010, "China's high saving rate: Myth and reality," BIS Working Paper No. 312, Bank of International Settlement, Basel.

Mellens, Martin C., Herman G.A. Noordman and Johan P. Verbruggen, 2007, "Re-exports: International comparison and implications for performance indicators," Central Planbureau (CPB) Document No. 149, Netherlands Bureau for Economic Policy Analysis, The Hague, the Netherlands.

Miroudot, Sebastien and Alexandros Ragoussis, 2009, "Vertical trade, trade costs and FDI," OECD Trade Policy Working Paper No. 89, OECD, Paris, France.

NRC (National Research Council), 2006, "Analyzing the US content of imports and the foreign content of exports," The National Academy Press, Washington, DC [online; cited November 2010]. Available from: http://books.nap.edu/catalog/11612.html.

Ping, Xinqiao, 2005, "Vertical specialization, intra-industry trade and Sino-US trade relationship," China Center for Economic Research, Peking University Working Paper No. C2005-005, Peking University, Beijing.

Prasad, Eswar, 2009, "Rebalancing growth in Asia," NBER Working Paper No. 15169, National Bureau of Economic Research, Cambridge, MA.

Roos, Jasper, 2006, "Identifying and measuring re-exports and re-imports," OECD, Statistics Directorate, Paper for 7th OECD International Trade Statistics Expert Meeting (ITS) and OECD-Eurostat Meeting of Experts in Trade-in-services; 11-13 September, Paris.

Suyker, Wim, 2007, "The Chinese economy, seen from Japan and the Netherlands," Central Planbureau (CPB) Memorandum No. 185, Netherlands Bureau for Economic Policy Analysis, The Hague, the Netherlands.

UNCTAD TDR, various issues, Trade and Development Report, Geneva: United Nations.

Wolfe, Adam and Rachel Ziemba, 2009, "What is China's exit strategy?" Roubini Global Economics, 16 November [online; cited November 2010].Available from: www.roubini.com/analysis.

World Bank CQU, various issues, China Quarterly Update, Beijing: World Bank Beijing Office. Yongding, Yu, 2007, "Global Imbalances and China," The Australian Economic Review, Vol. 40, No. 1, pp. 3-23.

(Edited by Xiaoming Feng) 